\title{
Yeast Cell-Based Transport Assay for the Functional Characterization of Human 4F2hc-LAT1 and -LAT2, and LAT1 and LAT2 Substrates and Inhibitors
}

\author{
Satish Kantipudi and Dimitrios Fotiadis * \\ Institute of Biochemistry and Molecular Medicine, University of Bern, Bern, Switzerland
}

OPEN ACCESS

Edited by:

Cesare Indiveri,

University of Calabria, Italy

Reviewed by:

Manuel Palacin

Institute for Research in Biomedicine,

Spain

Andreas H. Engel,

University of Basel, Switzerland

${ }^{*}$ Correspondence:

Dimitrios Fotiadis

dimitrios.fotiadis@ibmm.unibe.ch

Specialty section:

This article was submitted to

Cellular Biochemistry,

a section of the journal

Frontiers in Molecular Biosciences

Received: 06 March 2021

Accepted: 06 May 2021

Published: 28 May 2021

Citation:

Kantipudi S and Fotiadis D (2021) Yeast Cell-Based Transport Assay for

the Functional Characterization of Human 4F2hc-LAT1 and -LAT2, and

LAT1 and LAT2 Substrates and Inhibitors.

Front. Mol. Biosci. 8:676854. doi: 10.3389/fmolb.2021.676854
In mammalian cells, the L-type amino acid transporters (LATs) LAT1 (SLC7A5) and LAT2 (SLC7A8) form heterodimeric amino acid transporters (HATS) with the ancillary protein 4F2hc and are involved in the cellular uptake of specific amino acids. The HAT 4F2hc-LAT1 is found upregulated in various cancer cell types, while 4F2hc-LAT2 is a transporter for non-cancer cells. Preclinical studies have highlighted that 4F2hc-LAT1 plays an important role in tumor progression representing a valid anticancer target. Consequently, current research is focusing on the development of potent and specific human 4F2hc-LAT1 inhibitors. On the other hand, 4F2hc-LAT2 is emerging as target of other diseases, thus also gaining clinical interest. To determine affinity and specificity of substrates and inhibitors for 4F2hc-LAT1 or 4F2hc-LAT2, robust transport cell assays are indispensable. We have optimized and validated a transport assay using cells of the methylotrophic yeast Pichia pastoris stably overexpressing the human HATs 4F2hc-LAT1 or -LAT2, and the LATs LAT1 or LAT2 alone. The radioligand $\left[{ }^{3} \mathrm{H}\right] \mathrm{L}$-leucine was used as reporter and the substrates L-leucine, triiodothyronine (T3) and thyroxine (T4) as well as the inhibitors BCH and JPH2O3 (KYT-0353) for assay validation. Obtained half-maximal inhibitory concentrations also provided new insights, e.g., into the LAT specificity of the potent inhibitor JPH2O3 and on the potency of the thyroid hormones T3 and T4 to inhibit transport through human 4F2hc-LAT2. The LAT1 and LAT2 assays are of particular interest to determine possible implications and influences of 4F2hc in ligand binding and transport. In summary, the presented assays are valuable for characterization of ligands, e.g., towards 4F2hc-LAT1 specificity, and can also be applied for compound screening. Finally, our established approach and assay would also be applicable to other HATs and LATs of interest.

Keywords: amino acid transporter, inhibitor, LAT1, LAT2, JPH203, Pichia pastoris, SLC7, Transport Assay 


\section{INTRODUCTION}

Amino acids have diverse and essential roles in cell function, e.g., for protein synthesis, metabolism, signal transduction, neural transmission, and cellular growth and proliferation. Transport of amino acids across biological membranes is mediated by amino acid transporters, which are embedded in lipid bilayers of cells (Christensen, 1990; McGivan and Pastor-Anglada, 1994). Malfunction, absence or overexpression of amino acid transporters can affect homeostasis in the body leading to human diseases. The solute carrier (SLC) superfamily includes currently eleven families containing amino acid transporters (Kandasamy et al., 2018). The SLC7 family of amino acid transporters consists of fifteen genes and is split into two subgroups: the cationic amino acid transporters (CATs) and the L-type amino acid transporters (LATs) (Verrey et al., 2004; Fotiadis et al., 2013). CATs comprise the SLC7A1-A4 and SLC7A14 genes, and LATs the SLC7A5-A11, Slc7a12, SLC7A13, and Slc7a15 genes (Fotiadis et al., 2013). In contrast to CATs, LATs are not glycosylated. For correct trafficking to the plasma membrane in mammalian cells, LATs associated with type II membrane N-glycoproteins from the SLC3 family, i.e., 4F2hc (SLC3A2; CD98) and rBAT (SLC3A1) (Palacin and Kanai, 2004). These ancillary proteins (the heavy chains) are covalently connected to the corresponding LATs (the light subunits) through a conserved disulfide bridge to form heterodimeric amino acid transporters (HATs) (Chillaron et al., 2001; Wagner et al., 2001; Palacin and Kanai, 2004; Verrey et al., 2004; Fotiadis et al., 2013). The light subunits are the catalytic subunits of HATs (Reig et al., 2002; Rosell et al., 2014; Napolitano et al., 2015).

LAT1 (SLC7A5) and LAT2 (SLC7A8) are isoforms of the system $\mathrm{L}$ of amino acid transporters requiring the heavy chain 4F2 (4F2hc) for functional expression at the plasma membrane (Kanai et al., 1998; Pineda et al., 1999; Segawa et al., 1999). Furthermore, we recently showed that $4 \mathrm{~F} 2 \mathrm{hc}$ can modulate the substrate affinity and specificity of the light chains LAT1 and LAT2 (Kantipudi et al., 2020). In addition to these two LAT specific functions, the ancillary protein $4 \mathrm{~F} 2 \mathrm{hc}$ has multifunctional roles such as in cell adhesion, cell fusion, integrin signaling and regulation of macrophage activation via galectin-3 (Fenczik et al., 1997; Tsurudome and Ito, 2000; Feral et al., 2005; MacKinnon et al., 2008). 4F2hc-LAT1 is expressed in different tissues and organs (e.g., brain, ovary, placenta and testis), and in relatively high levels at the blood-brain barrier and in several types of tumors (Fotiadis et al., 2013; Scalise et al., 2018; Häfliger and Charles, 2019). The location and high expression levels make 4F2hcLAT1 an interesting vehicle for drug delivery into the brain and for cancer cell targeting (Häfliger and Charles, 2019; Puris et al., 2020). In cancer cells, 4F2hc-LAT1 provides neutral and essential amino acids for nutrition and regulation of the mTOR signaling pathway (Nicklin et al., 2009). Thus, inhibition of this HAT represents a valid approach to block migration and invasion of cancer cells, and to induce apoptosis. In contrast, 4F2hc-LAT2 is ubiquitously expressed in the human body and highly expressed in polarized epithelia suggesting a major role of this HAT in transepithelial transport of amino acids (Bröer, 2008; Fotiadis et al., 2013). Thus, both transporters have evolved towards specific functions, e.g., LAT1 for uptake of specific amino acids into growing cells, and LAT2 towards normal cell-type and transcellular amino acid transport.
LAT1 and LAT2 are sodium-independent transporters that exchange substrates across membranes with a one-to-one stoichiometry (Verrey et al., 2004; Fotiadis et al., 2013). The substrate specificities of both HATs are comparable, but 4F2hcLAT2 accepts in addition to large neutral also small neutral amino acids (Pineda et al., 1999; Rossier et al., 1999; Meier et al., 2002). Other substrates of 4F2hc-LAT1 and -LAT2 represent amino acid derivatives such as the thyroid hormones T3 and T4 (Friesema et al., 2001; Zevenbergen et al., 2015). The compound 2aminobicyclo-(2,2,1)-heptane-2-carboxylic acid (BCH) (Kim et al,, 2008) was described as specific inhibitor of system L inhibiting both, 4F2hc-LAT1 and -LAT2 (Kanai et al., 1998; Segawa et al., 1999). On the other hand, the tyrosine-based JPH203 (KYT-0353) molecule was reported as a competitive, potent and highly specific 4F2hc-LAT1 inhibitor with strong inhibitory effects on the growth of different cancer cells (Oda et al., 2010; Yun et al., 2014; Häfliger et al., 2018). Therefore, transport inhibitors with high specificity towards $4 \mathrm{~F} 2 \mathrm{hc}$ LAT1 but not -LAT2 represent promising drug candidates for cancer therapy and diagnosis. In crescentic glomerulonephritis pathogenesis, LAT2 was shown to be upregulated activating the mTORC1 pathway (Kurayama et al., 2011). Thus, LAT2-specific inhibitors might also be interesting and considered therapeutically for crescentic glomerulonephritis and other emerging LAT2-related diseases. Towards discovery of potent and selective inhibitors against 4F2hcLAT1 or -LAT2, robust assays for ligand screening and functional characterization using cells overexpressing corresponding LATs separately are crucial. Establishment of mammalian cell lines for stable expression of $4 \mathrm{~F} 2 \mathrm{hc}-\mathrm{LAT} 1$ and -LAT2 is not straightforward since most host cell lines express HATs endogenously. As a consequence, the activity of the exogenous LAT is difficult to distinguish from the endogenous one and the limited endogenous pool of $4 \mathrm{~F} 2 \mathrm{hc}$ is used for both, endogenous and exogenous LATs, thus introducing ambiguities in the assays. Khunweeraphong et al. reported the establishment of stable HEK293 cell lines expressing exogenous LAT1 or LAT2, and using endogenous $4 \mathrm{~F} 2 \mathrm{hc}$ of the cells to form HATs (Khunweeraphong et al., 2012). HEK293 cells indicated reduced backgrounds of amino acid transport, e.g., reduced contamination of endogenous LAT1 activity (Khunweeraphong et al., 2012), and other advantages compared to the murine S2 cells previously used in a similar endeavor (Morimoto et al., 2008).

The methylotrophic yeast Pichia pastoris represents a wellestablished system for the expression of recombinant human membrane proteins (Byrne, 2015). Cholesterol and derivatives thereof were shown to play an important role in function and stability of LATs (Meury et al., 2014; Dickens et al., 2017; Cosco et al., 2020). Yeasts such as $P$. pastoris produce ergosterol (Nes et al., 1978) providing a valuable cholesterol derivate for interaction with heterologously expressed membrane proteins. Towards establishment of a robust assay for ligand screening and functional characterization, we have optimized, applied and validated a previously reported radioligand assay using $P$. pastoris overexpressing human $4 \mathrm{~F} 2 \mathrm{hc}-$ LAT1 or -LAT2, and the substrate $\left[{ }^{3} \mathrm{H}\right] \mathrm{L}$-leucine as radioligand. In contrast to the previously reported HEK293 cell assay (Khunweeraphong et al., 2012), 4F2hc is co-expressed with LAT1 or LAT2 in the Pichia-based assay, thus not limiting 4F2hc availability and boosting expression of HATs (Costa et al., 2013; Rosell et al., 2014; Kantipudi et al., 2020). Interestingly, 


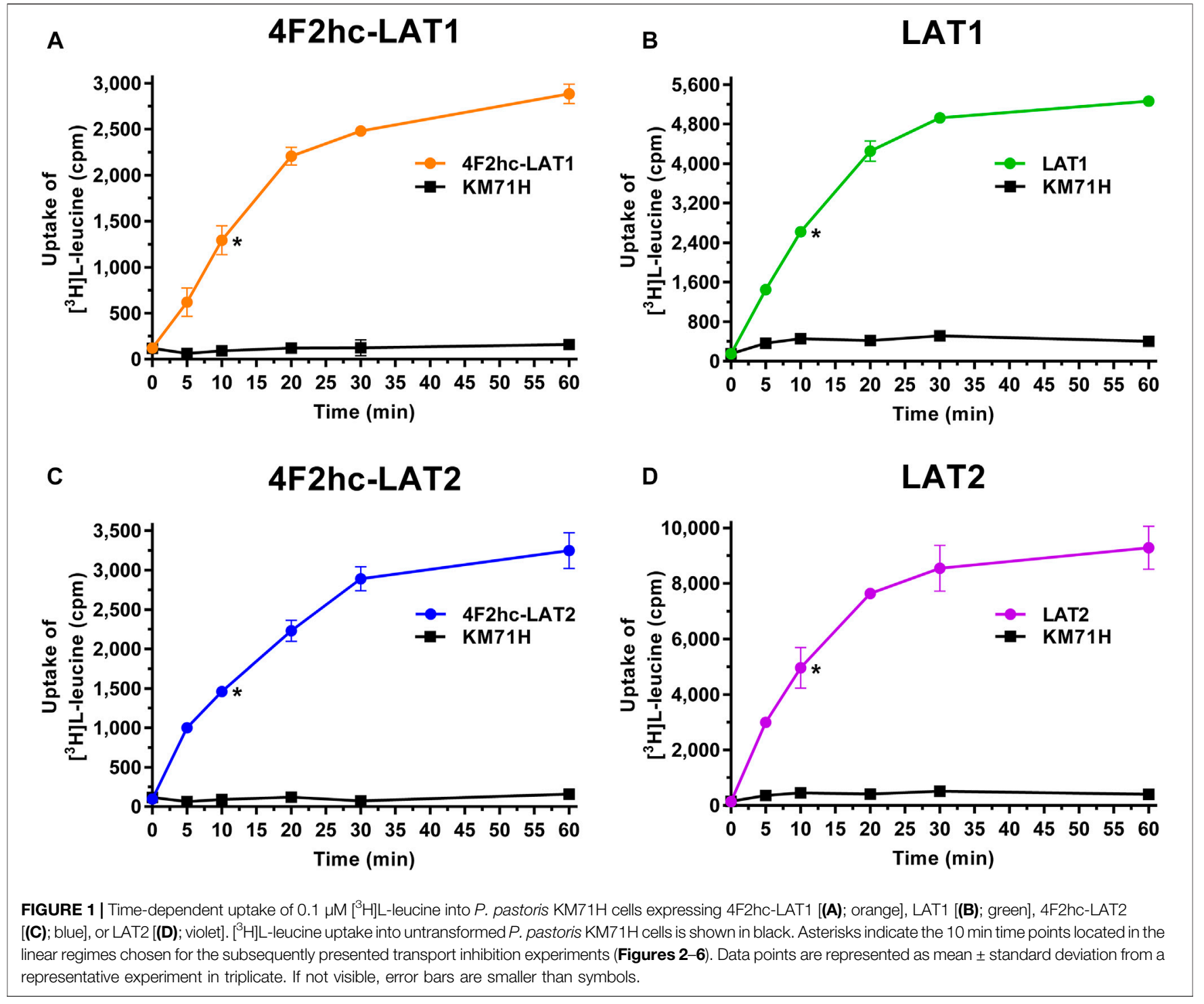

and in absence of $4 \mathrm{~F} 2 \mathrm{hc}$ co-expression, Pichia is also able to express functionally the light subunits LAT1 and LAT2 alone (Costa et al., 2013; Rosell et al., 2014; Kantipudi et al., 2020). This allows evaluating possible contributions of the heavy chain $4 \mathrm{~F} 2 \mathrm{hc}$ on ligand binding and transport inhibition through selected substrates and inhibitors.

\section{MATERIALS AND METHODS \\ Cloning and Expression in $P$. pastoris of Human 4F2hc-LAT1, LAT1, 4F2hc-LAT2 and LAT2}

Cloning of the human HATs and LATs into the pPICZB vector (Thermo Fisher Scientific, Waltham, MA, United States), electrotransformation of competent $P$. pastoris strain $\mathrm{KM} 71 \mathrm{H}$ cells (Thermo Fisher Scientific, Waltham, MA, United States) and selection of clones with high protein expression levels was performed as described in detail previously: see for $4 \mathrm{~F} 2 \mathrm{hc}$ LAT1 and LAT1 (Kantipudi et al., 2020), and for 4F2hc-LAT2 and LAT2 (Costa et al., 2013). Cell growth and expression conditions of Pichia clones overexpressing human 4F2hcLAT1, LAT1, 4F2hc-LAT2 or LAT2, and untransformed $P$. pastoris $\mathrm{KM} 71 \mathrm{H}$ cells (control) was conducted according to Kantipudi et al. (Kantipudi et al., 2020). Resulting cells were resuspended in transport buffer $(150 \mathrm{mM}$ choline chloride, $1 \mathrm{mM}$ $\mathrm{MgCl}_{2}, 1 \mathrm{mM} \mathrm{CaCl}, 10 \mathrm{mM}$ Tris-HEPES, $\mathrm{pH}$ 7.4) containing $50 \%(\mathrm{v} / \mathrm{v})$ glycerol and the $\mathrm{OD}_{600}$ was adjusted to 40 . Cells were stored at $-18^{\circ} \mathrm{C}$ until further use.

\section{$\left[{ }^{3} \mathrm{H}\right] \mathrm{L}-$ Leucine Radioligand Transport Assay}

For transport studies, $1 \mathrm{ml}$ of thawed $P$. pastoris cells $\left(\mathrm{OD}_{600} 40\right)$ expressing the corresponding transporter were diluted in $50 \mathrm{ml}$ transport buffer and pelleted by centrifugation $(3,000 \times g, 15 \mathrm{~min}$, room temperature). The pellet was then washed by resuspending it in $50 \mathrm{~mL}$ transport buffer and by repeating the washing procedure 


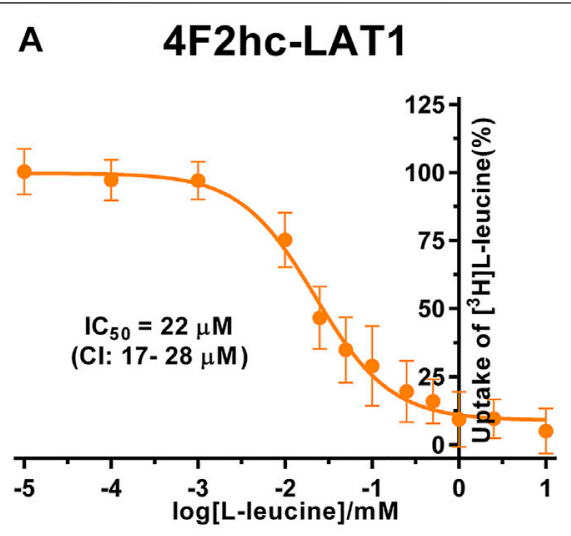

C 4F2hC-LAT2

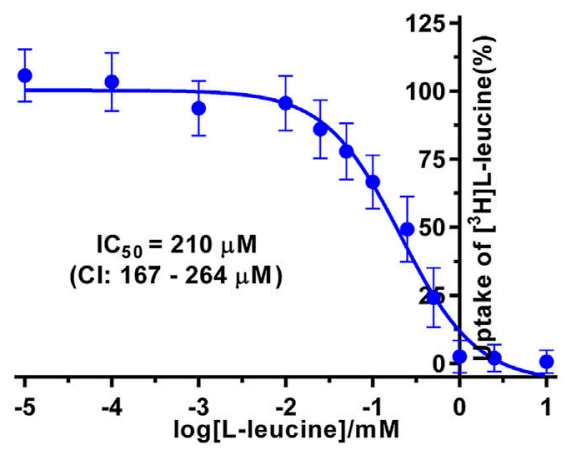

B LAT1
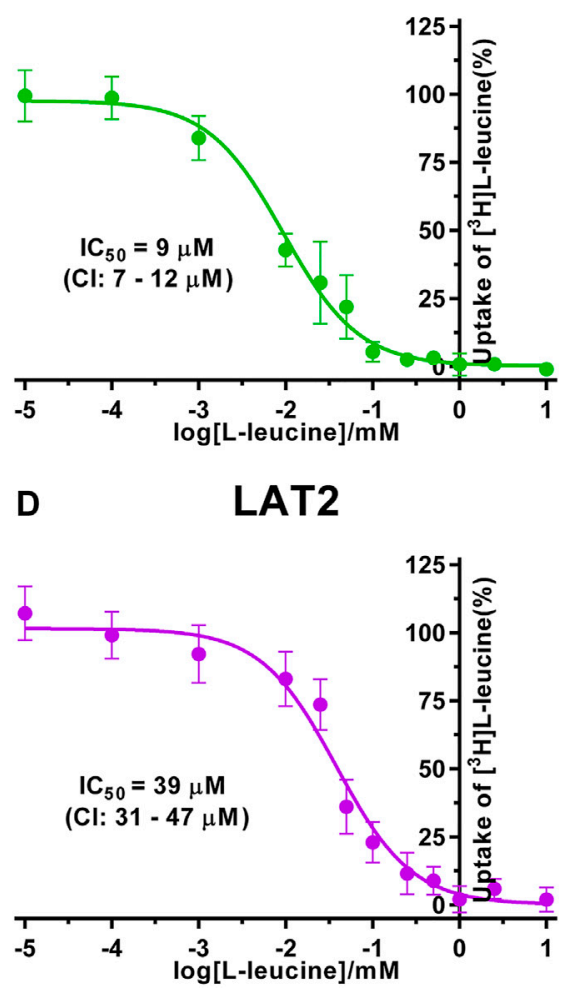

FIGURE 2 | IC 50 determination of L-leucine for human 4F2hc-LAT1 [(A); orange], LAT1 [(B); green], 4F2hc-LAT2 [(C); blue] and LAT2 [(D); violet] using P. pastoris $\mathrm{KM} 71 \mathrm{H}$ cells expressing the corresponding transporter variants. Determined $I_{50}$ values and $95 \%$ confidence intervals (Cls) are indicated. Mean \pm standard deviation of normalized data from three independent experiments, each at least in triplicate, are shown. If not visible, error bars are smaller than symbols.

(centrifugation and resuspension) two times. Finally, the cell pellet was resuspended in $2 \mathrm{ml}$ of transport buffer and incubated for $20 \mathrm{~min}$ at $30^{\circ} \mathrm{C}$ under agitation $(300 \mathrm{rpm}$, Multitron, Infors HT, Bottmingen, Switzerland). The yeast suspension density was adjusted with transport buffer to an $\mathrm{OD}_{600}$ of 1.875 (4F2hc-LAT1, LAT1, 4F2hcLAT2 or LAT2, and untransformed $P$. pastoris KM71H cells). All transport experiments were performed in a reaction volume of $100 \mu \mathrm{L}$. For time-dependent $\left[{ }^{3} \mathrm{H}\right] \mathrm{L}$-leucine uptake experiments (Figure 1), the reaction mixture contained $40 \mu \mathrm{L}$ cell suspension and $60 \mu \mathrm{L}$ substrate master mix [0.167 $\mu \mathrm{M}$ L-leucine spiked with $\left[{ }^{3} \mathrm{H}\right] \mathrm{L}$-leucine (American Radiolabeled Chemicals, St. Louis, MO, United States)] with a specific activity of $20 \mathrm{Ci} / \mathrm{mmol}$ resulting in a final L-leucine concentration of $0.1 \mu \mathrm{M}$. $\mathrm{IC}_{50}$ determinations of selected compounds for the transporters 4F2hc-LAT1, LAT1, 4F2hc-LAT2, or LAT2 were performed using $40 \mu \mathrm{L}$ cell suspension, $50 \mu \mathrm{L}$ of competitor solution at different concentrations and $10 \mu \mathrm{L}$ substrate master mix $\left[1 \mu \mathrm{M}\right.$ L-leucine spiked with $\left[{ }^{3} \mathrm{H}\right] \mathrm{L}$-leucine (American Radiolabeled Chemicals, St. Louis, MO, United States)] with a specific activity of $20 \mathrm{Ci} / \mathrm{mmol}$ resulting in a final L-leucine concentration of $0.1 \mu \mathrm{M}$. For L-leucine and BCH (2-aminobicyclo(2,2,1)-heptane-2-carboxylic acid) $\mathrm{IC}_{50}$ experiments, the competitor solutions were at concentrations of $0.01-10,000 \mu \mathrm{M} \mathrm{L}$-leucine (4F2hcLAT1, LAT1, 4F2hc-LAT2, and LAT2), and 0.25-1,000 $\mu \mathrm{M} \mathrm{BCH}$ (4F2hc-LAT1 and LAT1) and 1-5,000 $\mu \mathrm{M} \mathrm{BCH} \mathrm{(4F2hc-LAT2} \mathrm{and}$
LAT2)-see corresponding graphs in Figures 2, 3 for specific concentrations used. For determining the $\mathrm{IC}_{50}$ values of hydrophobic compounds such as JPH203 [(S)-2-amino-3-(4-((5amino-2-phenylbenzo [d] oxazol-7-yl)-methoxy)-3,5dichlorophenyl)-propanoic acid] also known as KYT-0353 (MedChemExpress, Monmouth Junction, NJ, United States), and the thyroid hormones T3 (triiodothyronine) and T4 (thyroxine) (Sigma, St. Louis, MO, United States), $40 \mu \mathrm{L}$ of cell suspension was incubated with $50 \mu \mathrm{L}$ of competitor solutions at different concentrations for $60 \mathrm{~min}$ at $25^{\circ} \mathrm{C}$ under agitation $(500 \mathrm{rpm}$, Thermomixer compact, Eppendorf, Hamburg, Germany). The uptake was initiated by adding $10 \mu \mathrm{L}$ substrate master mix $[1 \mu \mathrm{M}$ L-leucine spiked with $\left[{ }^{3} \mathrm{H}\right] \mathrm{L}$-leucine (American Radiolabeled Chemicals, St. Louis, MO, United States)] with a specific activity of $20 \mathrm{Ci} / \mathrm{mmol}$ to the preincubated $90 \mu \mathrm{L}$ of reaction volume resulting in a final L-leucine concentration of $0.1 \mu \mathrm{M}$. Final ligand concentrations in $100 \mu \mathrm{L}$ were $0.001-250 \mu \mathrm{M}$ (JPH203, T3, and T4). The competitors were prepared in $100 \%(\mathrm{v} / \mathrm{v})$ DMSO. The final DMSO concentration was always $0.5 \%(\mathrm{v} / \mathrm{v})$, independently of which final substrate or inhibitor concentration was used in the assay. Control samples contained the same concentration of DMSO. Final $\mathrm{OD}_{600}$ values in uptake experiments were 0.75 for all cells (4F2hc-LAT1, LAT1, 4F2hc-LAT2 or LAT2 expressing cells) and untransformed P. pastoris $\mathrm{KM} 71 \mathrm{H}$ cells. All transport reactions were done in $2 \mathrm{ml}$ reaction tubes 

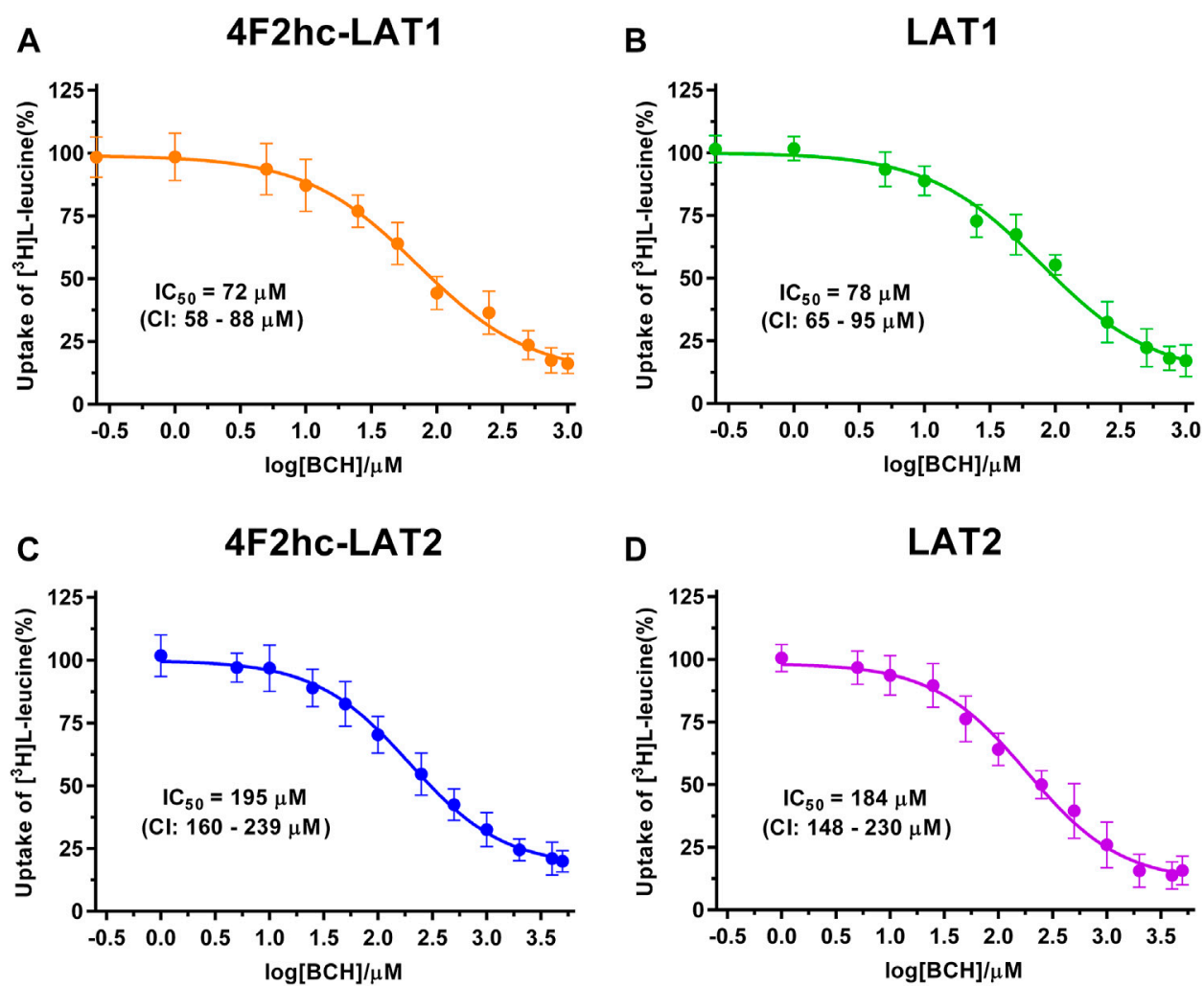

FIGURE 3 | IC I0 $_{50}$ determination of BCH for human 4F2hc-LAT1 [(A); orange], LAT1 [(B); green], 4F2hc-LAT2 [(C); blue] and LAT2 [(D); violet] using P. pastoris $\mathrm{KM} 71 \mathrm{H}$ cells expressing the corresponding transporter variants. Determined $\mathrm{IC}_{50}$ values and $95 \%$ confidence intervals (Cls) are indicated. Mean \pm standard deviation of normalized data from three independent experiments, each at least in triplicate, are shown. If not visible, error bars are smaller than symbols.

(Eppendorf, Hamburg, Germany) at $25^{\circ} \mathrm{C}$ under agitation (1,000 rpm, Thermomixer compact, Eppendorf, Hamburg, Germany). Uptakes were terminated after 10 min (uptake time) for all cells by adding $600 \mu \mathrm{L}$ of pre-chilled transport buffer. Cells were rapidly separated from the buffer by transferring the stopped reactions on a 96-well $0.66 \mathrm{~mm}$ glass fiber filter plate (Corning FiltrEX, Corning, NY, United States) and vacuum filtration. Each well was washed with $2 \mathrm{ml}$ of ice-cold transport buffer to remove free radioligand. The plate was then dried overnight at $37^{\circ} \mathrm{C}$, and the backside was sealed with a BackSeal (PerkinElmer, Waltham, MA, United States). The trapped radioligand was released by addition of $200 \mu \mathrm{L}$ scintillation cocktail (MicroScint 40, PerkinElmer, Waltham, MA, United States) to each well, and the plate topside was sealed with Topseal ${ }^{\mathrm{TM}}-\mathrm{A}$ Plus (PerkinElmer, Waltham, MA, United States), followed by incubation for $30 \mathrm{~min}$ at $25^{\circ} \mathrm{C}$ and $1,000 \mathrm{rpm}$ (Thermomixer compact, Eppendorf, Hamburg, Germany). Counts were measured in each well for $2 \mathrm{~min}$ with a scintillation counter (TopCount NXT, PerkinElmer, Waltham, MA, United States).

\section{Data Analysis, Curve Fitting and Statistics}

Experiments were performed at least in triplicate. For data analysis, the signal of the untransformed $P$. pastoris cells was subtracted from the transporter signal to obtain the net transport signal. Data from three independent experiments were taken. In each of these experiments, the net transport signals were averaged and the half maximal inhibitory concentration $\left(\mathrm{IC}_{50}\right)$ values of homologous (L-leucine) and heterologous (BCH, JPH203, T3, and T4) L-leucine transport competition experiments were determined by fitting a sigmoidal model curve to these data. Every experimental data point was then individually normalized using the corresponding upper plateau values (i.e., the fitted upper plateau value that corresponds to 100\%). Single, normalized data points from the three independent experiments were averaged and a sigmoidal model curve was fitted to the data in order to obtain the $\mathrm{IC}_{50}$ values. Prism6 (GraphPad Software) was used for data analysis.

\section{RESULTS}

Human 4F2hc-LAT1, LAT1, 4F2hc-LAT2 or LAT2 were expressed in the methylotrophic yeast $P$. pastoris. We showed in previous reports that not only the HATs 4F2hc-LAT1 and -LAT2, but also the light subunits LAT1 and LAT2 in absence of ancillary protein are properly folded, correctly trafficked to the plasma membrane and functional in P. pastoris (Rosell et al., 2014; Kantipudi et al., 2020).

Transport activities were determined by measuring the uptake of the substrate $\left[{ }^{3} \mathrm{H}\right] \mathrm{L}$-leucine into Pichia cells at $\mathrm{OD}_{600} 0.75$ expressing the corresponding HAT or LAT. Time-course experiments showed clear HAT- and LAT-dependent transport activities, which were much higher than the $\left[{ }^{3} \mathrm{H}\right] \mathrm{L}$-leucine uptake into untransformed 

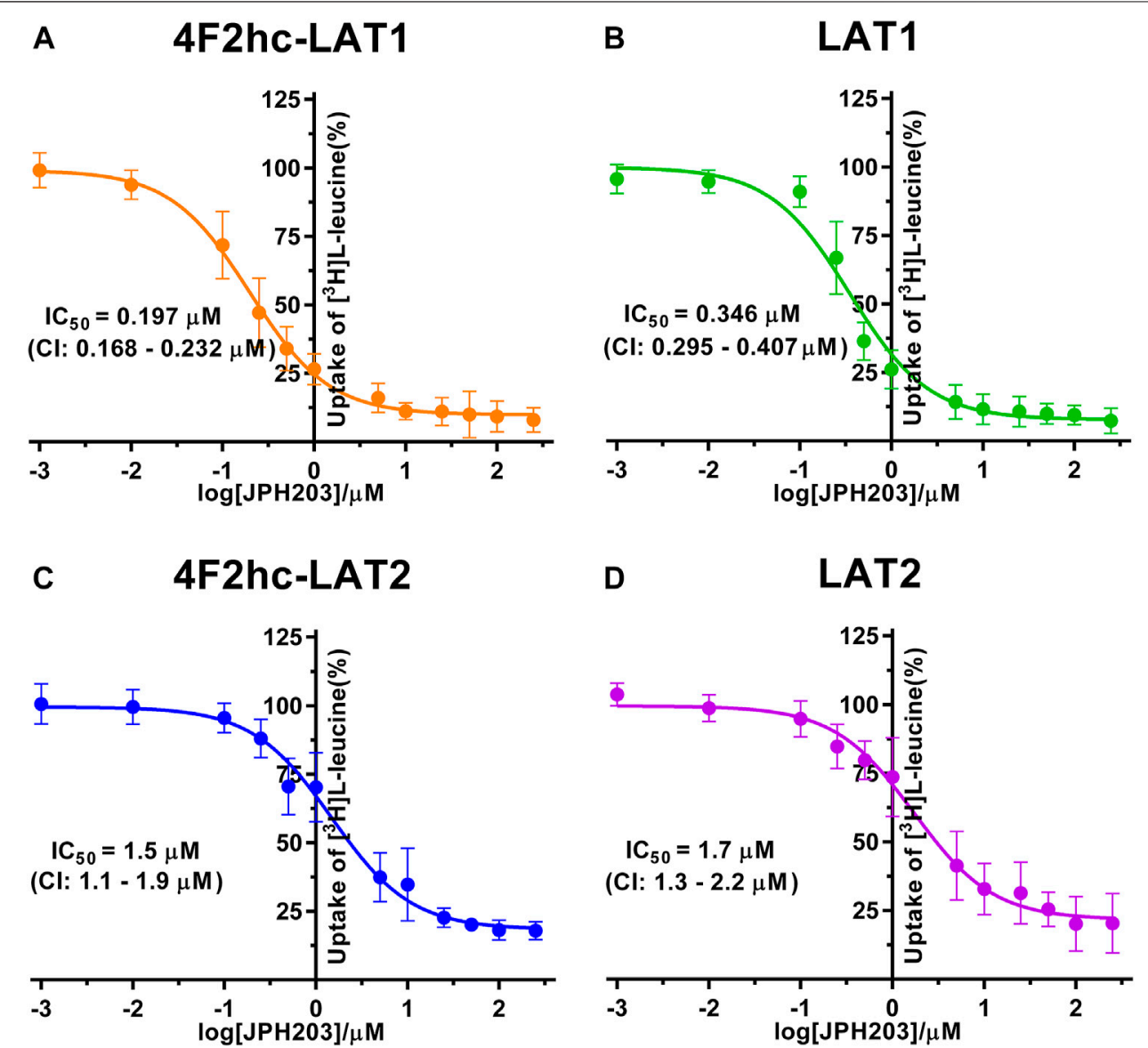

FIGURE 4 | IC $\mathrm{C}_{50}$ determination of JPH203 for human 4F2hc-LAT1 [(A); orange], LAT1 [(B); green], 4F2hc-LAT2 [(C); blue] and LAT2 [(D); violet] using P. pastoris $\mathrm{KM} 71 \mathrm{H}$ cells expressing the corresponding transporter variants. Determined $I_{5} \mathrm{C}_{50}$ values and $95 \%$ confidence intervals (Cls) are indicated. Mean \pm standard deviation of normalized data from three independent experiments, each at least in triplicate, are shown. If not visible, error bars are smaller than symbols.

host cells (Figure 1). In all cases, saturation of the transport process was observed. Differences in radioligand transport (Figure 1) are due to different expression levels of corresponding recombinant LATs as estimated from $\mathrm{V}_{\max } / \mathrm{OD}$ values using previously determined kinetic parameters (Kantipudi et al., 2020). Uptake assay times of $10 \mathrm{~min}$ (i.e., in the linear regimes-time points indicated by asterisks in Figure 1) and corresponding Pichia cells at $\mathrm{OD}_{600} 0.75$ were taken for the subsequently presented experiments with 4F2hc-LAT1, LAT1, 4F2hc-LAT2, and LAT2 (Figures 2-6).

We determined the half-maximal inhibitory concentrations $\left(\mathrm{IC}_{50} \mathrm{~s}\right)$ of L-leucine by homologous competition for all four transporter variants. Obtained $\mathrm{IC}_{50}$ values were $22 \mu \mathrm{M}$ (4F2hc-LAT1), $9 \mu \mathrm{M}$ (LAT1), $210 \mu \mathrm{M}$ (4F2hc-LAT2), and $39 \mu \mathrm{M}$ (LAT2) (Figure 2).

As previously reported (Kantipudi et al., 2020), comparison of $\mathrm{IC}_{50} \mathrm{~s}$ indicated a modulatory effect of the heavy subunit $4 \mathrm{~F} 2$ on light subunits, which is most striking between 4F2hc-LAT2 and LAT2 (Figure 2). After validation of the yeast-cell based transport assay with the substrate L-leucine (Figures 1, 2), we pursued validation using the described system $\mathrm{L}$ transport inhibitor $\mathrm{BCH}$ (Kim et al., 2008) and the 4F2hc-LAT1 specific inhibitor JPH203 (Oda et al., 2010). We obtained $\mathrm{IC}_{50}$ values of $72 \mu \mathrm{M}$ (4F2hc-
LAT1), $78 \mu \mathrm{M}$ (LAT1), $195 \mu \mathrm{M}$ (4F2hc-LAT2), and $184 \mu \mathrm{M}$ (LAT2) for $\mathrm{BCH}$ (Figure 3). These results indicated that the compound $\mathrm{BCH}$ inhibits both human HATs being about 2.7-fold more specific for $4 \mathrm{~F} 2 \mathrm{hc}-\mathrm{LAT} 1$. Interestingly, and in contrast to L-leucine (Figure 2), LAT1 and LAT2 in absence of 4F2hc had comparable $\mathrm{IC}_{50} \mathrm{~s}$ as their heterodimeric forms (Figure 3) indicating no significant influence of the ancillary protein on BCH binding to LATs of HATs.

For the second inhibitor, i.e., JPH203, $\mathrm{IC}_{50}$ values of $0.197 \mu \mathrm{M}$ (4F2hc-LAT1), $0.346 \mu \mathrm{M}$ (LAT1), $1.5 \mu \mathrm{M}$ (4F2hc-LAT2) and $1.7 \mu \mathrm{M}$ (LAT2) were obtained using our yeast cell-based assay (Figure 4). Clearly, the compound JPH203 is with its three-digit nanomolar $\mathrm{IC}_{50}$ value potent and about 7.6 -fold more specific for 4F2hc-LAT1 compared with 4F2hc-LAT2. As observed also with $\mathrm{BCH}, \mathrm{IC}_{50}$ values of JPH203 were comparable for $4 \mathrm{~F} 2 \mathrm{hc}$-LAT1 and LAT1, and 4F2hc-LAT2 and LAT2, indicating no significant effect of the ancillary protein on inhibitor binding.

The thyroid hormones triiodothyronine (T3) and thyroxine (T4) represent substrates of 4F2hc-LAT1 and -LAT2 (Friesema et al., 2001; Zevenbergen et al., 2015). We selected these amino acid derivatives as substrates for further validation of our $P$. 

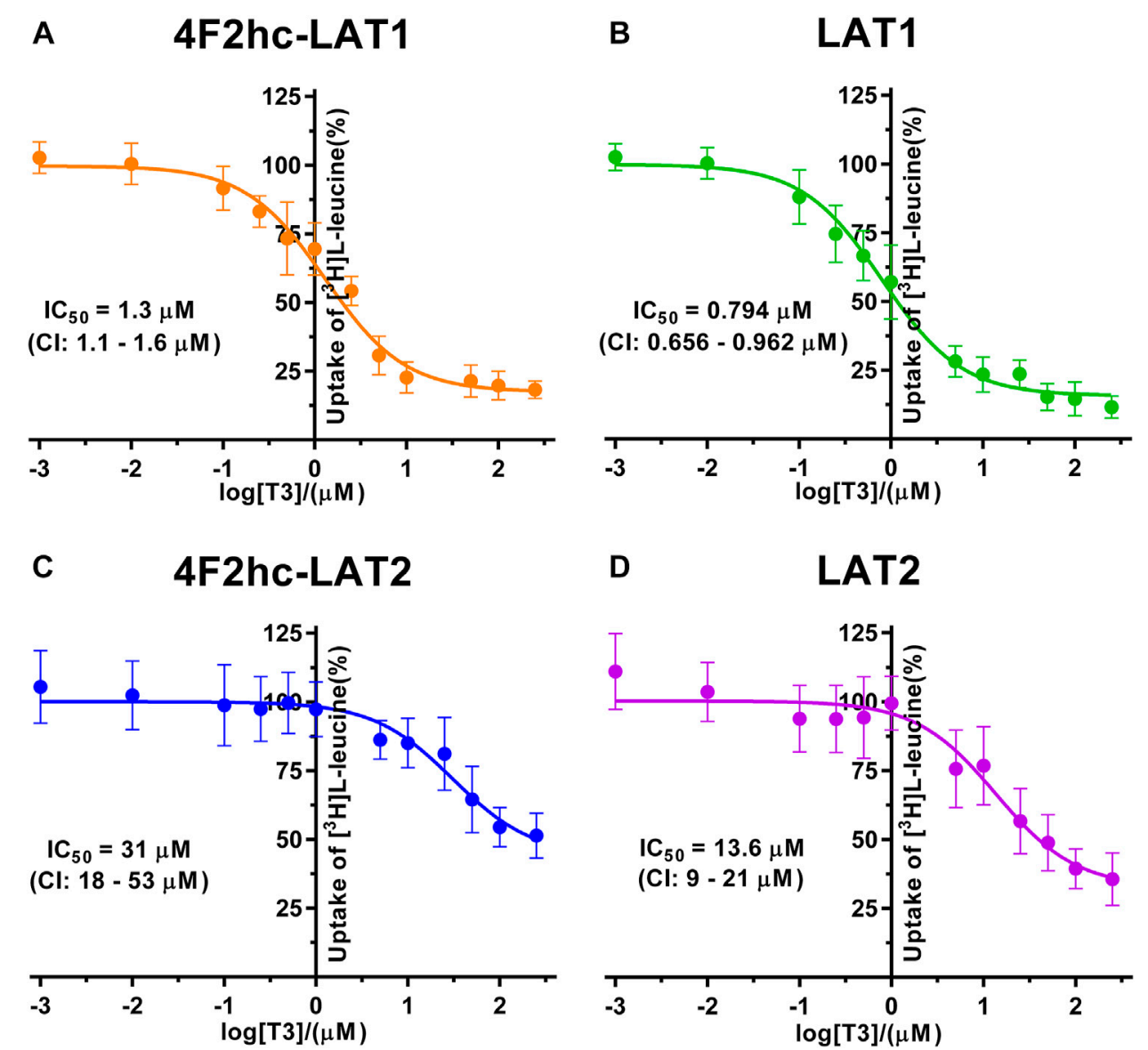

FIGURE 5 | IC 50 determination of T3 for human 4F2hc-LAT1 [(A); orange], LAT1 [(B); green], 4F2hc-LAT2 [(C); blue] and LAT2 [(D); violet] using P. pastoris KM71H cells expressing the corresponding transporter variants. Determined $\mathrm{IC}_{50}$ values and $95 \%$ confidence intervals (Cls) are indicated. Mean \pm standard deviation of normalized data from three independent experiments, each at least in triplicate, are shown. If not visible, error bars are smaller than symbols.

pastoris cell-based transport assay. For triiodothyronine, we obtained $\mathrm{IC}_{50}$ values of $1.3 \mu \mathrm{M} \quad(4 \mathrm{~F} 2 \mathrm{hc}-\mathrm{LAT} 1), 0.794 \mu \mathrm{M}$ (LAT1), $\quad 31 \mu \mathrm{M} \quad$ (4F2hc-LAT2), and $13.6 \mu \mathrm{M} \quad$ (LAT2) (Figure 5). The inhibitory effect of T3 was considerably more pronounced for 4F2hc-LAT1 and LAT1 compared with 4F2hcLAT2 and LAT2, e.g., about 24-fold lower $\mathrm{IC}_{50}$ value for 4F2hcLAT1 in comparison with 4F2hc-LAT2.

Finally, we determined the $\mathrm{IC}_{50} \mathrm{~s}$ of the thyroid hormone thyroxine using our yeast cell-based transport assay and obtained $\mathrm{IC}_{50}$ values of $10 \mu \mathrm{M}$ (4F2hc-LAT1), $8 \mu \mathrm{M}$ (LAT1), $42 \mu \mathrm{M}$ (4F2hc-LAT2), and $25 \mu \mathrm{M}$ (LAT2) (Figure 6). Similar to triiodothyronine, the thyroxine hormone also competed with $\left[{ }^{3} \mathrm{H}\right] \mathrm{L}$-leucine uptake through $4 \mathrm{~F} 2 \mathrm{hc}-\mathrm{LAT} 1$, LAT1, 4F2hc-LAT2, and LAT2. The transport inhibitory effect and thus specificity of T4 was about four-times higher for $4 \mathrm{~F} 2 \mathrm{hc}-$ LAT1 compared with 4F2hc-LAT2. A comparable trend was observed for the light subunits LAT1 and LAT2. The presence of the heavy chain $4 \mathrm{~F} 2$ had no marked or only a weak effect on the $\mathrm{IC}_{50}$ values of $4 \mathrm{~F} 2 \mathrm{hc}-\mathrm{LAT} 1(10 \mu \mathrm{M})$ and $4 \mathrm{~F} 2 \mathrm{hc}-\mathrm{LAT} 2$ $(42 \mu \mathrm{M})$ compared to the light subunits LAT1 $(8 \mu \mathrm{M})$ and LAT1 $(25 \mu \mathrm{M})$ alone.

\section{DISCUSSION}

A cell-based transport assay using the methylotrophic yeast $P$. pastoris overexpressing the human HATs 4F2hc-LAT1 or -LAT2, and LATs LAT1 or LAT2, and the radiolabeled substrate $\left[{ }^{3} \mathrm{H}\right] \mathrm{L}$-leucine was optimized and validated using selected substrates and inhibitors. In contrast to our previous study (Kantipudi et al., 2020), we adjusted uptake time and $\mathrm{OD}_{600}$ for the four stably expressing Pichia clones to same conditions, i.e., to $10 \mathrm{~min}$ and $\mathrm{OD}_{600} 0.75$ (Figure 1). For comparison and validation of the adjusted uptake conditions, $\mathrm{IC}_{50} \mathrm{~s}$ were determined for the substrate L-leucine (Figure 2)-the here studied transporters have high affinities for L-leucine relative to the other proteinogenic amino acids (Kantipudi et al., 2020). The obtained $\mathrm{IC}_{50} \mathrm{~s}$ for L-leucine (Figure 2) were comparable to previously published values using oocytes (Kanai et al., 1998; Friesema et al., 2001; Yanagida et al., 2001), and P. pastoris cells at $\mathrm{OD}_{600} 10$ (4F2hcLAT1, 4F2hc-LAT2, and LAT1) and $\mathrm{OD}_{600} 3$ (LAT2), and uptake times of $10 \mathrm{~min}$ (4F2hc-LAT1, 4F2hc-LAT2, and LAT1) and $2 \mathrm{~min}$ (LAT2) (Kantipudi et al., 2020). The modulatory effect of the heavy chain $4 \mathrm{~F} 2$ on the L-leucine affinity of light subunits, this being most pronounced for $4 \mathrm{~F} 2 \mathrm{hc}$-LAT2 and LAT2 (Figures 2C,D), was also 

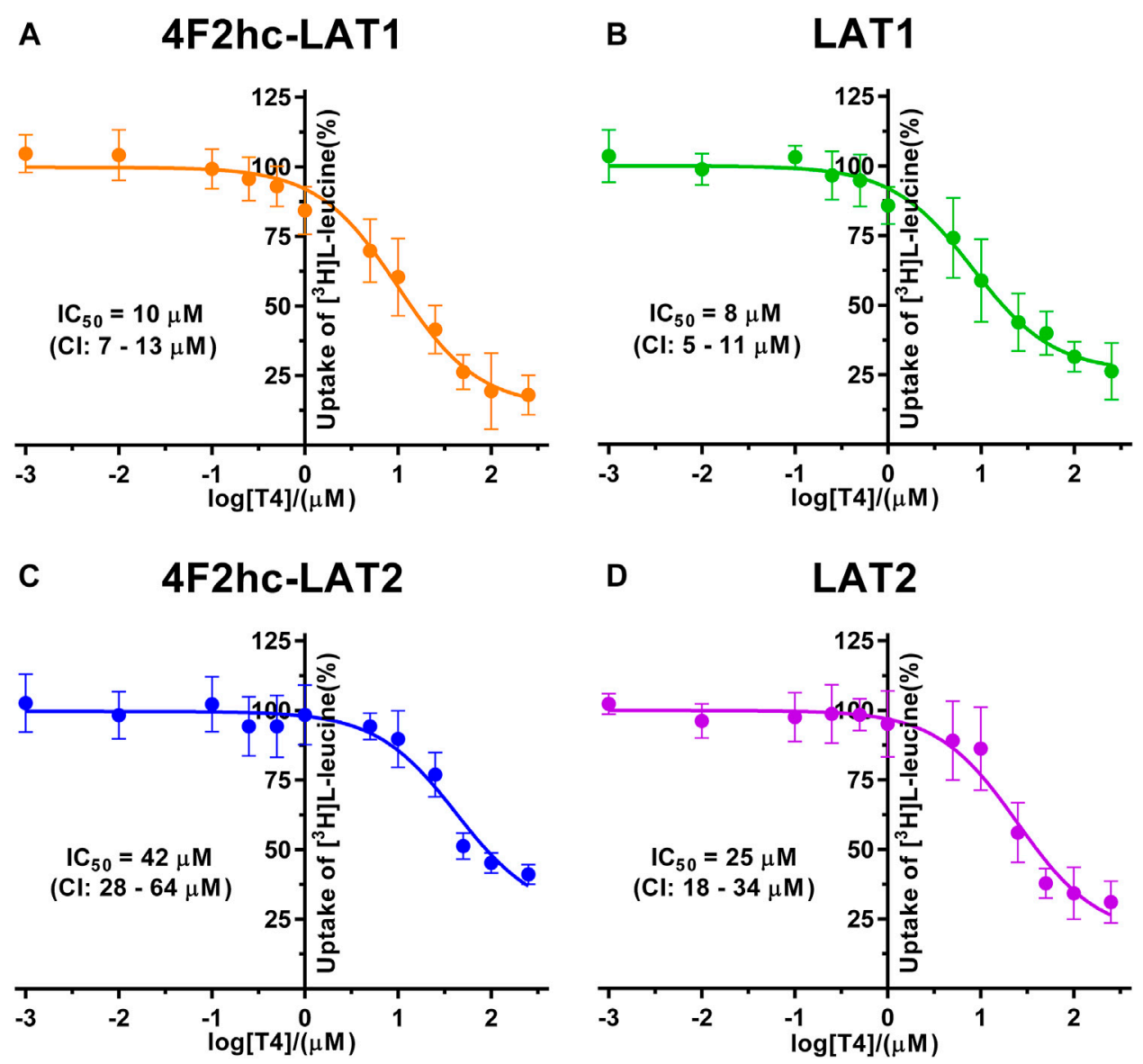

FIGURE 6 | IC 50 determination of T4 for human 4F2hc-LAT1 [(A); orange], LAT1 [(B); green], 4F2hc-LAT2 [(C); blue] and LAT2 [(D); violet] using P. pastoris KM71H cells expressing the corresponding transporter variants. Determined $I_{50}$ values and $95 \%$ confidence intervals (Cls) are indicated. Mean \pm standard deviation of normalized data from three independent experiments, each at least in triplicate, are shown. If not visible, error bars are smaller than symbols.

observed in line with our previous report (Kantipudi et al., 2020). Newly, we tested with the $P$. pastoris cell-based assay, described transport inhibitors, i.e., the system L and 4F2hc-LAT1 uptake inhibitors BCH (Kim et al., 2008) and JPH203 (Oda et al., 2010), respectively. The $\mathrm{IC}_{50} \mathrm{~s}$ of $\mathrm{BCH}$ for the two HATs were comparable with values from the literature (Table 1) and almost identical to the $\mathrm{IC}_{50} \mathrm{~s}$ from corresponding LATs in absence of $4 \mathrm{~F} 2 \mathrm{hc}$ (Figure 3). The latter indicated no contribution of the ancillary protein on $\mathrm{BCH}$ binding to light subunits. JPH203 was described as a competitive, potent and highly specific 4F2hc-LAT1 inhibitor (Endou et al., 2008; Oda et al., 2010). The authors of these two studies determined $\mathrm{IC}_{50} \mathrm{~s}$ of $0.14 \mu \mathrm{M}$ (Oda et al., 2010), and 0.19 and $0.2 \mu \mathrm{M}$ (Endou et al., 2008) for human LAT1 HATs expressed in S2 cells derived from mouse renal proximal tubules (Morimoto et al., 2008) (Table 1). The $\mathrm{IC}_{50}$ of $0.197 \mu \mathrm{M}$ for $4 \mathrm{~F} 2 \mathrm{hc}$-LAT1 obtained with the here presented assay (Figure $4 \mathbf{A})$ is similar to the values $(0.14$, 0.19 , and $0.2 \mu \mathrm{M}$ ) determined for the same HAT using S2 cells (Table 1). Furthermore, most kinetic parameters for JPH203 and 4F2hc-LAT1 determined using other cell types than S2 cells were also in good agreement with the $\mathrm{IC}_{50}$ value from $P$. pastoris cells (Table 1). However, a marked difference is found between the $\mathrm{IC}_{50}$ of JPH203 determined for human $4 \mathrm{~F} 2 \mathrm{hc}-\mathrm{LAT} 2$ using the $P$. pastoris $(1.5 \mu \mathrm{M}$;
Figure 4C) and the S2 cell-based assays (>10 $\mu \mathrm{M}$ (Oda et al., 2010) and almost no inhibition at $10 \mu \mathrm{M}$ (Endou et al., 2008)). Furthermore, Oda et al. indicated an $\mathrm{IC}_{50}(\mathrm{~S} 2-\mathrm{LAT} 2) / \mathrm{IC}_{50}(\mathrm{~S} 2-\mathrm{LAT} 1)$ ratio of $>500$, which would be indicative of a high specificity of JPH203 towards human 4F2hc-LAT1 and not 4F2hc-LAT2 (Oda et al., 2010). In strong contrast, the $\mathrm{IC}_{50}$ (Pichia-4F2hc-LAT2)/IC ${ }_{50}$ (Pichia-4F2hc-LAT1) ratio was only about 7.6 , indicating a significantly more moderate specificity of JPH203 towards 4F2hc-LAT1. This finding was further corroborated independently using Pichia cells expressing the light subunits alone, which yielded a comparable $\mathrm{IC}_{50}$ (PichiaLAT2)/IC ${ }_{50}$ (Pichia-LAT1) ratio of about 4.9. Future studies on the specificity of JPH203 towards 4F2hc-LAT1 and -LAT2 will clarify this ambiguity. For further validation of our yeast cell-based transport assay, we tested amino acid derivatives, specifically the thyroid hormones T3 and T4, which are substrates of 4F2hc-LAT1 and -LAT2 (Friesema et al., 2001; Zevenbergen et al., 2015). For 4F2hcLAT1, T3 reflected a higher potency in transport inhibition than T4 (Figures 5A, 6A) in line with previous studies (Table 1). No kinetic parameters were found in the literature for $\mathrm{T} 3$ and $\mathrm{T} 4$ with $4 \mathrm{~F} 2 \mathrm{hc}$ LAT2 for comparison. Thus, our $\mathrm{IC}_{50}$ for $\mathrm{T} 3$ and $\mathrm{T} 4$ represent first 4F2hc-LAT2 and LAT2 specific kinetic values (Figures 5C,D, 6C,D). Based on the obtained $\mathrm{IC}_{50}$ s, the ancillary protein $4 \mathrm{~F} 2 \mathrm{hc}$ did 
TABLE 1 | Comparison of obtained with published 4F2hc-LAT1 and -LAT2 kinetic parameters.

\begin{tabular}{|c|c|c|c|c|}
\hline \multirow[t]{2}{*}{ Compound } & \multicolumn{3}{|c|}{ 4F2hc-LAT1 IC $\mathrm{I}_{50}, K_{\mathrm{M}}$ or $K_{\mathrm{i}}(\mu \mathrm{M})$ of L-leucine uptake } & \multirow[t]{2}{*}{ References } \\
\hline & This work $\left(\mathrm{IC}_{50}\right)$ & Kinetic parameters & Host & \\
\hline \multirow[t]{5}{*}{ L-leucine } & 22 & $38\left(1 \mathrm{C}_{50}\right)$ & Pichia pastoris & Kantipudi et al. (2020) \\
\hline & & $25 \pm 3\left(K_{M}\right)$ & & \\
\hline & & $46\left(K_{M}\right)$ & Oocytes & Friesema et al. (2001) \\
\hline & & $18.1 \pm 3.4\left(K_{M}\right)$ & & Kanai et al. (1998) \\
\hline & & $19.7 \pm 4.1\left(K_{M}\right)$ & & Yanagida et al. (2001) \\
\hline \multirow[t]{7}{*}{$\mathrm{BCH}$} & 72 & $72.17 \pm 0.92\left(\mathrm{IC}_{50}\right)$ & Saos2 & Choi et al. (2017) \\
\hline & & $78.8 \pm 3.5\left(\mathrm{IC}_{50}\right)$ & & Kim et al. (2008) \\
\hline & & $75.3 \pm 6.7\left(\mathrm{IC}_{50}\right)$ & KB cells & Kim et al. (2008) \\
\hline & & $73.1 \pm 4.5\left(\mathrm{IC}_{50}\right)$ & C6 cells & \\
\hline & & $92.6 \pm 8.9\left(\mathrm{IC}_{50}\right)$ & YD-38 & Yun et al. (2014) \\
\hline & & $78.3 \pm 12.1\left(\mathrm{IC}_{50}\right)$ & HEK293 & Khunweeraphong et al. (2012) \\
\hline & & $132 \pm 27.8\left(\mathrm{IC}_{50}\right)$ & S2 cells & Morimoto et al. (2008) \\
\hline \multirow[t]{10}{*}{ JPH2O3 } & 0.197 & $1.31 \pm 0.27\left(\mathrm{IC}_{50}\right)$ & Saos2 & Choi et al. (2017) \\
\hline & & $0.14\left(\mathrm{IC}_{50}\right)$ & S2 cells & Oda et al. (2010) \\
\hline & & 0.19 and $0.20\left(\mathrm{IC}_{50}\right)$ & & Endou et al. (2008) \\
\hline & & $0.79 \pm 0.06\left(\mathrm{IC}_{50}\right)$ & YD-38 & Yun et al. (2014) \\
\hline & & $0.134\left(\mathrm{IC}_{50}\right)$ & HТ-29 & Häfliger et al. (2018) \\
\hline & & $0.177\left(\mathrm{IC}_{50}\right)$ & SW1736 & \\
\hline & & $0.120\left(\mathrm{IC}_{50}\right)$ & $8505 c$ & \\
\hline & & $0.20 \pm 0.03\left(\mathrm{IC}_{50}\right)$ & KKU-055 & Yothaisong et al. (2017) \\
\hline & & $0.12 \pm 0.02\left(\mathrm{IC}_{50}\right)$ & $\mathrm{KKU}-213$ & \\
\hline & & $0.25 \pm 0.04\left(\mathrm{IC}_{50}\right)$ & KKU-100 & \\
\hline \multirow[t]{3}{*}{ T3 } & 1.3 & $0.8\left(K_{\mathrm{M}}\right)$ & Oocytes & Friesema et al. (2001) \\
\hline & & $1.8\left(K_{\mathrm{M}}\right)$ & & Ritchie et al. (1999) \\
\hline & & $1.7 \pm 0.1\left(K_{i}\right)$ & S2 cells & Morimoto et al. (2008) \\
\hline \multirow[t]{3}{*}{$\mathrm{T} 4$} & 10 & $7.9\left(K_{M}\right)$ & Oocytes & Friesema et al. (2001) \\
\hline & & $6.3\left(K_{M}\right)$ & & Ritchie et al. (1999) \\
\hline & & $115 \pm 2.0\left(K_{\mathrm{i}}\right)$ & S2 cells & Morimoto et al. (2008) \\
\hline \multirow[t]{2}{*}{ Compound } & \multicolumn{3}{|c|}{ 4F2hc-LAT2 $\mathrm{IC}_{50}, K_{\mathrm{M}}$ or $K_{\mathrm{i}}(\mu \mathrm{M})$ of L-leucine uptake } & References \\
\hline & This work $\left(\mathrm{IC}_{50}\right)$ & Kinetic parameters & Host & \\
\hline \multirow[t]{3}{*}{ L-leucine } & 210 & $221\left(\mathrm{IC}_{50}\right)$ & Pichia pastoris & Kantipudi et al. (2020) \\
\hline & & $249 \pm 22\left(K_{\mathrm{M}}\right)$ & & \\
\hline & & $220\left(K_{M}\right)$ & Oocytes & Pineda et al. (1999) \\
\hline $\mathrm{BCH}$ & 195 & $315 \pm 68.6\left(\mathrm{IC}_{50}\right)$ & S2 cells & Morimoto et al. (2008) \\
\hline JPH2O3 & 1.5 & $>10\left(\mathrm{IC}_{50}\right)$ & S2 cells & Oda et al. (2010) \\
\hline
\end{tabular}

not have an important influence on the binding of the two hormones to the light subunits (Figures 5, 6).

\section{CONCLUSION}

We have provided a robust yeast cell-based transport assay for the functional characterization of human 4F2hc-LAT1 and -LAT2, and LAT1 and LAT2 substrates and inhibitors. P. pastoris cells expressing HATs are valuable for determining kinetic parameters of ligands, e.g., potency and selectivity of transport inhibitors towards 4F2hc-LAT1 and -LAT2. Such kinetic information will help evaluating the structure-activity relationship of new ligands. Moreover, assays performed with yeast cells expressing light subunits provide kinetic parameters that, when compared with those of corresponding HATs, are of interest towards identification of possible effects of the ancillary protein $4 \mathrm{~F} 2 \mathrm{hc}$ on ligand affinity and specificity. First kinetic parameters on T3 and T4 were successfully provided for human 4F2hc-LAT2 and LAT2 using the here presented yeast cell-based transport assay. Finally, the established approach and assay could also be used for compound screening and applied to other HATs and LATs of interest.

\section{DATA AVAILABILITY STATEMENT}

The raw data supporting the conclusions of this article will be made available by the authors, without undue reservation.

\section{AUTHOR CONTRIBUTIONS}

DF conceived and designed the study. SK performed the experiments, collected and analyzed the data. SK and DF wrote the manuscript. DF obtained the funding. SK and DF read, and approved the submitted version.

\section{FUNDING}

This research was funded by the University of Bern, the Swiss National Science Foundation and the Swiss National Centre of Competence in Research (NCCR) TransCure.

\section{ACKNOWLEDGMENTS}

We thank Sara Bonetti and Jean-Marc Jeckelmann for valuable feedback on the manuscript. 


\section{REFERENCES}

Bröer, S. (2008). Amino Acid Transport across Mammalian Intestinal and Renal Epithelia. Physiol. Rev. 88 (1), 249-286. doi:10.1152/physrev.00018.2006

Byrne, B. (2015). Pichia pastoris as an Expression Host for Membrane Protein Structural Biology. Curr. Opin. Struct. Biol. 32, 9-17. doi:10.1016/j.sbi.2015. 01.005

Chillarón, J., Roca, R., Valencia, A., Zorzano, A., and Palacín, M. (2001). Heteromeric Amino Acid Transporters: Biochemistry, Genetics, and Physiology. Am. J. Physiology-Renal Physiol. 281, F995-F1018. doi:10.1152/ ajprenal.2001.281.6.f995

Choi, D. W., Kim, D. K., Kanai, Y., Wempe, M. F., Endou, H., and Kim, J.-K. (2017). JPH203, a Selective L-type Amino Acid Transporter 1 Inhibitor, Induces Mitochondria-dependent Apoptosis in Saos2 Human Osteosarcoma Cells. Korean J. Physiol. Pharmacol. 21 (6), 599-607. doi:10.4196/kjpp.2017.21.6.599

Christensen, H. N. (1990). Role of Amino Acid Transport and Countertransport in Nutrition and Metabolism. Physiol. Rev. 70 (1), 43-77. doi:10.1152/physrev. 1990.70.1.43

Cosco, J., Scalise, M., Colas, C., Galluccio, M., Martini, R., Rovella, F., et al. (2020). ATP Modulates SLC7A5 (LAT1) Synergistically with Cholesterol. Sci. Rep. 10 (1), 16738. doi:10.1038/s41598-020-73757-y

Costa, M., Rosell, A., Álvarez-Marimon, E., Zorzano, A., Fotiadis, D., and Palacín, M. (2013). Expression of Human Heteromeric Amino Acid Transporters in the Yeast Pichia pastoris. Protein Expr. Purif. 87 (1), 35-40. doi:10.1016/j.pep.2012. 10.003

Dickens, D., Chiduza, G. N., Wright, G. S. A., Pirmohamed, M., Antonyuk, S. V., and Hasnain, S. S. (2017). Modulation of LAT1 (SLC7A5) Transporter Activity and Stability by Membrane Cholesterol. Sci. Rep. 7, 43580. doi:10.1038/ srep 43580

Endou, H., Kanai, Y., Saito, K., and Oda, K. (2008). Aromatic Amino Acid Derivative with LAT1 Inhibitory Activity, LAT1 Inhibitor Containing the Same and Method for Producing the Same. Patent Publication No. WO2008081537 International Application No. PCT/JP2006/326233.

Fenczik, C. A., Sethi, T., Ramos, J. W., Hughes, P. E., and Ginsberg, M. H. (1997). Complementation of Dominant Suppression Implicates CD98 in Integrin Activation. Nature 390 (6655), 81-85. doi:10.1038/36349

Feral, C. C., Nishiya, N., Fenczik, C. A., Stuhlmann, H., Slepak, M., and Ginsberg, M. H. (2005). CD98hc (SLC3A2) Mediates Integrin Signaling. Proc. Natl. Acad. Sci. 102 (2), 355-360. doi:10.1073/pnas.0404852102

Fotiadis, D., Kanai, Y., and Palacín, M. (2013). The SLC3 and SLC7 Families of Amino Acid Transporters. Mol. Aspects Med. 34 (2-3), 139-158. doi:10.1016/j. mam.2012.10.007

Friesema, E. C. H., Docter, R., Moerings, E. P. C. M., Verrey, F., Krenning, E. P., Hennemann, G., et al. (2001). Thyroid Hormone Transport by the Heterodimeric Human System L Amino Acid Transporter. Endocrinology 142 (10), 4339-4348. doi:10.1210/endo.142.10.8418

Häfliger, P., and Charles, R.-P. (2019). The L-type Amino Acid Transporter LAT1An Emerging Target in Cancer. Ijms 20 (10), 2428. doi:10.3390/ijms20102428

Häfliger, P., Graff, J., Rubin, M., Stooss, A., Dettmer, M. S., Altmann, K.-H., et al. (2018). The LAT1 Inhibitor JPH203 Reduces Growth of Thyroid Carcinoma in a Fully Immunocompetent Mouse Model. J. Exp. Clin. Cancer Res. 37 (1), 234. doi:10.1186/s13046-018-0907-z

Kanai, Y., Segawa, H., Miyamoto, K.-i., Uchino, H., Takeda, E., and Endou, H. (1998). Expression Cloning and Characterization of a Transporter for Large Neutral Amino Acids Activated by the Heavy Chain of 4F2 Antigen (CD98). J. Biol. Chem. 273 (37), 23629-23632. doi:10.1074/jbc.273.37.23629

Kandasamy, P., Gyimesi, G., Kanai, Y., and Hediger, M. A. (2018). Amino Acid Transporters Revisited: New Views in Health and Disease. Trends Biochem. Sci. 43 (10), 752-789. doi:10.1016/j.tibs.2018.05.003

Kantipudi, S., Jeckelmann, J.-M., Ucurum, Z., Bosshart, P. D., and Fotiadis, D. (2020). The Heavy Chain 4F2hc Modulates the Substrate Affinity and Specificity of the Light Chains LAT1 and LAT2. Ijms 21 (20), 7573. doi:10. 3390/ijms21207573

Khunweeraphong, N., Nagamori, S., Wiriyasermkul, P., Nishinaka, Y., Wongthai, P., Ohgaki, R., et al. (2012). Establishment of Stable Cell Lines with High Expression of Heterodimers of Human 4F2hc and Human Amino Acid Transporter LAT1 or LAT2 and Delineation of Their Differential
Interaction with alpha-Alkyl Moieties. J. Pharmacol. Sci. 119 (4), 368-380. doi:10.1254/jphs.12124fp

Kim, C. S., Cho, S.-H., Chun, H. S., Lee, S.-Y., Endou, H., Kanai, Y., et al. (2008). $\mathrm{BCH}$, an Inhibitor of System L Amino Acid Transporters, Induces Apoptosis in Cancer Cells. Biol. Pharm. Bull. 31 (6), 1096-1100. doi:10.1248/bpb.31.1096

Kurayama, R., Ito, N., Nishibori, Y., Fukuhara, D., Akimoto, Y., Higashihara, E., et al. (2011). Role of Amino Acid Transporter LAT2 in the Activation of mTORC1 Pathway and the Pathogenesis of Crescentic Glomerulonephritis. Lab. Invest. 91 (7), 992-1006. doi:10.1038/labinvest.2011.43

MacKinnon, A. C., Farnworth, S. L., Hodkinson, P. S., Henderson, N. C., Atkinson, K. M., Leffler, H., et al. (2008). Regulation of Alternative Macrophage Activation by Galectin-3. J. Immunol. 180 (4), 2650-2658. doi:10.4049/ jimmunol.180.4.2650

McGivan, J. D., and Pastor-Anglada, M. (1994). Regulatory and Molecular Aspects of Mammalian Amino Acid Transport. Biochem. J. 299 (Pt 2), 321-334. doi:10. 1042/bj2990321

Meier, C., Ristic, Z., Klauser, S., and Verrey, F. (2002). Activation of System L Heterodimeric Amino Acid Exchangers by Intracellular Substrates. EMBO J. 21 (4), 580-589. doi:10.1093/emboj/21.4.580

Meury, M., Costa, M., Harder, D., Stauffer, M., Jeckelmann, J.-M., Brühlmann, B., et al. (2014). Detergent-induced Stabilization and Improved 3D Map of the Human Heteromeric Amino Acid Transporter 4F2hc-LAT2. PLoS ONE 9, e109882. doi:10.1371/journal.pone.0109882

Morimoto, E., Kanai, Y., Kim, D. K., Chairoungdua, A., Choi, H. W., Wempe, M. F., et al. (2008). Establishment and Characterization of Mammalian Cell Lines Stably Expressing Human L-type Amino Acid Transporters. J. Pharmacol. Sci. 108 (4), 505-516. doi:10.1254/jphs.08232fp

Napolitano, L., Scalise, M., Galluccio, M., Pochini, L., Albanese, L. M., and Indiveri, C. (2015). LAT1 Is the Transport Competent Unit of the LAT1/CD98 Heterodimeric Amino Acid Transporter. Int. J. Biochem. Cell Biol. 67, 25-33. doi:10.1016/j.biocel.2015.08.004

Nes, W. R., Sekula, B. C., Nes, W. D., and Adler, J. H. (1978). The Functional Importance of Structural Features of Ergosterol in Yeast. J. Biol. Chem. 253 (17), 6218-6225. doi:10.1016/s0021-9258(17)34602-1

Nicklin, P., Bergman, P., Zhang, B., Triantafellow, E., Wang, H., Nyfeler, B., et al. (2009). Bidirectional Transport of Amino Acids Regulates mTOR and Autophagy. Cell 136 (3), 521-534. doi:10.1016/j.cell.2008.11.044

Oda, K., Hosoda, N., Endo, H., Saito, K., Tsujihara, K., Yamamura, M., et al. (2010). L-type Amino Acid Transporter 1 Inhibitors Inhibit Tumor Cell Growth. Cancer Sci. 101 (2), 173-179. doi:10.1111/j.1349-7006.2009.01386.x

Palacín, M., and Kanai, Y. (2004). The Ancillary Proteins of HATs: SLC3 Family of Amino Acid Transporters. Pflugers Arch. 447 (5), 490-494. doi:10.1007/s00424003-1062-7

Pineda, M., Fernández, E., Torrents, D., Estévez, R., López, C., Camps, M., et al. (1999). Identification of a Membrane Protein, LAT-2, that Co-expresses with 4F2 Heavy Chain, an L-type Amino Acid Transport Activity with Broad Specificity for Small and Large Zwitterionic Amino Acids. J. Biol. Chem. 274 (28), 19738-19744. doi:10.1074/jbc.274.28.19738

Puris, E., Gynther, M., Auriola, S., and Huttunen, K. M. (2020). L-Type Amino Acid Transporter 1 as a Target for Drug Delivery. Pharm. Res. 37 (5), 88. doi:10. 1007/s11095-020-02826-8

Reig, N., Chillaron, J., Bartoccioni, P., Fernandez, E., Bendahan, A., Zorzano, A., et al. (2002). The Light Subunit of System Bo,+ Is Fully Functional in the Absence of the Heavy Subunit. EMBO J. 21, 4906-4914. doi:10.1093/emboj/ cdf500

Ritchie, J., Peter, G., Shi, Y., and Taylor, P. (1999). Thyroid Hormone Transport by 4F2hc-IU12 Heterodimers Expressed in Xenopus Oocytes. J. Endocrinol. 163 (2), R5-R9. doi:10.1677/joe.0.163r005

Rosell, A., Meury, M., Alvarez-Marimon, E., Costa, M., Perez-Cano, L., Zorzano, A., et al. (2014). Structural Bases for the Interaction and Stabilization of the Human Amino Acid Transporter LAT2 with its Ancillary Protein 4F2hc. Proc. Natl. Acad. Sci. 111 (8), 2966-2971. doi:10.1073/pnas.1323779111

Rossier, G., Meier, C., Bauch, C., Summa, V., Sordat, B., Verrey, F., et al. (1999). LAT2, a New Basolateral 4F2hc/CD98-Associated Amino Acid Transporter of Kidney and Intestine. J. Biol. Chem. 274 (49), 34948-34954. doi:10.1074/jbc. 274.49.34948

Scalise, M., Galluccio, M., Console, L., Pochini, L., and Indiveri, C. (2018). The Human SLC7A5 (LAT1): The Intriguing Histidine/large Neutral Amino Acid 
Transporter and its Relevance to Human Health. Front. Chem. 6, 243. doi:10. 3389/fchem.2018.00243

Segawa, H., Fukasawa, Y., Miyamoto, K.-i., Takeda, E., Endou, H., and Kanai, Y. (1999). Identification and Functional Characterization of a Na+-independent Neutral Amino Acid Transporter with Broad Substrate Selectivity. J. Biol. Chem. 274 (28), 19745-19751. doi:10.1074/jbc.274.28.19745

Tsurudome, M., and Ito, Y. (2000). Function of Fusion Regulatory Proteins (FRPs) in Immune Cells and Virus-Infected Cells. Crit. Rev. Immunol. 20 (3), 30-196. doi:10.1615/CritRevImmunol.v20.i3.10

Verrey, F., Closs, E. I., Wagner, C. A., Palacin, M., Endou, H., and Kanai, Y. (2004). CATs and HATs: the SLC7 Family of Amino Acid Transporters. Pflugers Archiv Eur. J. Physiol. 447 (5), 532-542. doi:10.1007/s00424-003-1086-z

Wagner, C. A., Lang, F., and Bröer, S. (2001). Function and Structure of Heterodimeric Amino Acid Transporters. Am. J. Physiology-Cell Physiol. 281 (4), C1077-C1093. doi:10.1152/ajpcell.2001.281.4.C1077

Yanagida, O., Kanai, Y., Chairoungdua, A., Kim, D. K., Segawa, H., Nii, T., et al. (2001). Human L-type Amino Acid Transporter 1 (LAT1): Characterization of Function and Expression in Tumor Cell Lines. Biochim. Biophys. Acta (Bba) Biomembranes 1514, 291-302. doi:10.1016/s0005-2736(01)00384-4

Yothaisong, S., Dokduang, H., Anzai, N., Hayashi, K., Namwat, N., Yongvanit, P., et al. (2017). Inhibition of L-type Amino Acid Transporter 1 Activity as a New
Therapeutic Target for Cholangiocarcinoma Treatment. Tumour Biol. 39 (3), 101042831769454. doi:10.1177/1010428317694545

Yun, D.-W., Lee, S. A., Park, M.-G., Kim, J.-S., Yu, S.-K., Park, M.-R., et al. (2014). JPH203, an L-type Amino Acid Transporter 1-selective Compound, Induces Apoptosis of YD-38 Human Oral Cancer Cells. J. Pharmacol. Sci. 124 (2), 208-217. doi:10.1254/jphs.13154fp

Zevenbergen, C., Meima, M. E., Lima De Souza, E. C., Peeters, R. P., Kinne, A., Krause, G., et al. (2015). Transport of Iodothyronines by Human L-type Amino Acid Transporters. Endocrinology 156 (11), 4345-4355. doi:10.1210/en.20151140

Conflict of Interest: The authors declare that the research was conducted in the absence of any commercial or financial relationships that could be construed as a potential conflict of interest.

Copyright $\odot 2021$ Kantipudi and Fotiadis. This is an open-access article distributed under the terms of the Creative Commons Attribution License (CC BY). The use, distribution or reproduction in other forums is permitted, provided the original author(s) and the copyright owner(s) are credited and that the original publication in this journal is cited, in accordance with accepted academic practice. No use, distribution or reproduction is permitted which does not comply with these terms. 